\title{
症例報告 VII
}

\section{成人 $\mathrm{T}$ 細胞性白血病が併存した肚門悪性リンパ腫の 1 例}

\author{
大橋 勝久 ${ }^{1)}$ 佐々木章公 ${ }^{1)}$ 松尾 嘉禮 ${ }^{1)}$ 大橋 勝英 ${ }^{2}$ \\ 十全総合病院 ${ }^{1)}$, 大橋胃腸科肛門科外科 ${ }^{2}$
}

直腸肛門悪性リンパ腫は大腸に発生する悪性疾患の約 $0.2 \%$ とまれで1), さらに肛門原発例は極めてまれ である ${ }^{2)}$. 海外では男性同性愛者に多く, 後天性免疫不全症候群による細胞性免疫の低下が発症の誘因と されている.しかしながら本邦では報告数が少ないため関連性は指摘されていない. 治療法も確立されて いるとはいえず，外科的切除や化学療法が有効との報告が多いが予後は極めて不良である．われわれは HTLV-1 キャリアーを以前から指摘され, 肛門悪性リンパ腫診断時に成人 T 細胞性白血病を合併してい た症例を経験した，化学療法を行ったが，早期に感染性合併症により治療関連死した。一連の経過から， 背景に強い細胞性免疫の低下があったと推察された。

索引用語 : 肚門悪性リンパ腫, 成人 T 細胞性白血病, 化学療法

\section{はじめに}

直腸悪性リンパ腫は大腸悪性腫瘍の約 $0.2 \%$ とま れな疾患であるが，肚門部に発症した悪性リンパ腫 の報告は極めて少ない。直腸肛門管原発の悪性リン パ腫では HIV や $\mathrm{EBV}$ の感染合併例が多く, 組織像 は non-Hodgikin’s Lymphoma（以下 NHL), B-cell Lymphoma が多数を占めている. 今回 Adult T-cell Lymphoma（以下 ATL）を合併し肛門管病変から 診断に至った Diffuse Large B Cell Lymphoma（以 下 DLBCL）を経験したので，文献的考察を加えて 報告する.

\section{症例}

患者：80 代，女性.

主訴：肛門痛.

既往歴：40 年以上前より HTLV-1 キャリアーを 指摘. 近医診療所で高血圧治療. 2 年間他院総合病 院皮膚科で肚門尖圭コンジローマを治療.

現病歴：1 力月前からの肛門痛で近医肛門科診療 所を受診し肚門腫瘍の診断で当科に紹介となった.

入院時現症 : 身長 $149 \mathrm{~cm}$, 体重 $50 \mathrm{~kg}$. 表在リンパ 節の腫脹を含め体表面に異常認めず.

入院時血液検査所見：異常リンパ球を主体 (46.7 \%) とした白血球上昇（31,300/ul）とATLA 抗原
陽性, 花弁状細胞（Fig. 1）の出現を認めた. LDH $396 \mathrm{IU} / l$, CRP $1.44 \mathrm{mg} / \mathrm{d} l$, CEA $5.1 \mathrm{ng} / \mathrm{m} l$, SCC $2.4 \mathrm{ng} / \mathrm{m} l$ と軽度上昇し, $\mathrm{sIL} 2-\mathrm{R}$ は $16,800 \mathrm{U} / \mathrm{m} l$ と著 明に上昇していた. HBs-Ag(-), HCV-Ab(-), $\operatorname{HIV}-\mathrm{Ab}(-), \operatorname{RPR}(-), \operatorname{TPHA}(-)$.

患者背景 : 出生地は愛媛県. 診断時家系内 ATL 発症者と HTLV-1 キャリアーはいなかったが，およ そ半年後に次男が ATLを発症した。

胸部 CT 検査：特記すべき異常はなかった.

腹部 CT 検査（Fig. 2A，B）：肝内に早期相で低吸 収を示す多発小腫瘤陰影を認めた。腹腔動脈を中心 としたリンパ節腫大を認めた。

骨盤 MRI 検查（Fig. 3A，B）：肚門管外左側を中 心に, $4.0 \times 4.2 \mathrm{~cm}$, T1WI で high〜 low intensity,

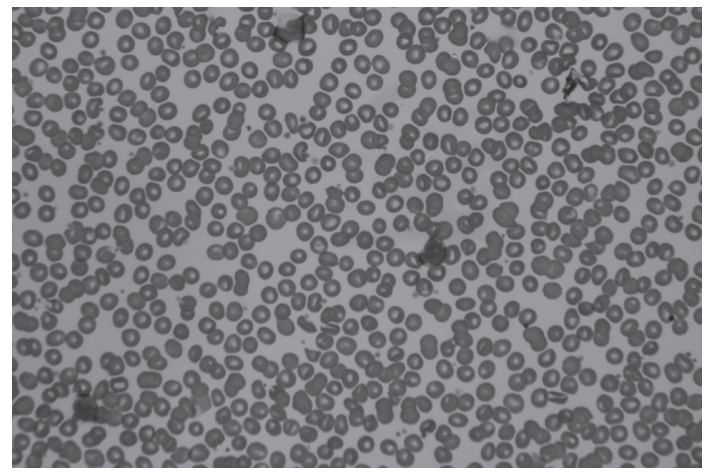

Fig. 1 末梢血液中に花弁状細胞の出現を認めた. 

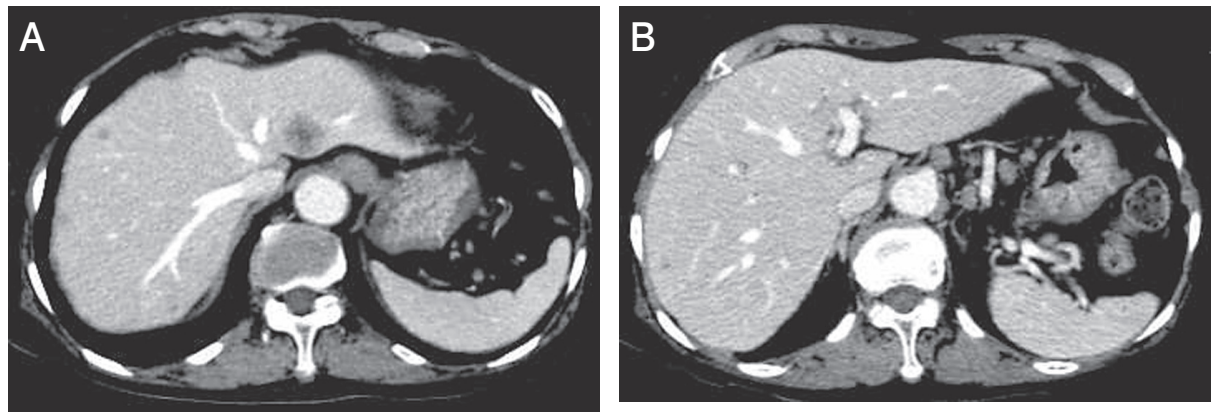

Fig. 2 CT 所見

A : 肝内に多発する低濃度腫瘤陰影を認めた。

$\mathrm{B}$ ：腹腔動脈周囲に腫大したリンパ節を認めた.
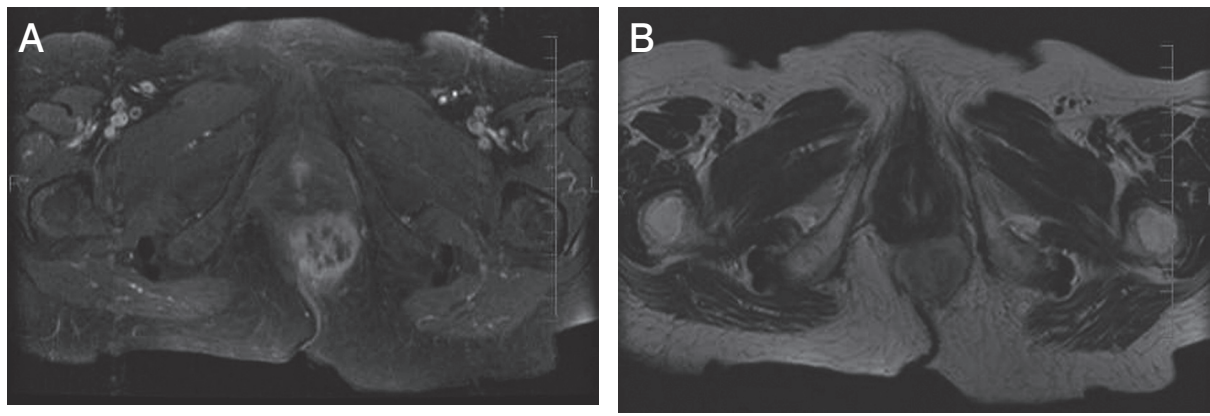

Fig. 3 MRI 所見

肛門管外の軟部組織に左側を首座とする, $4.0 \times 4.2 \mathrm{~cm}$ 大の腫瘤陰影を認めた.

A : T1WI で周辺 high intensity / 中央部 low intensity が混在した.

B : T2WI で周辺 iso intensity / 中心部 low intensity が混在した.
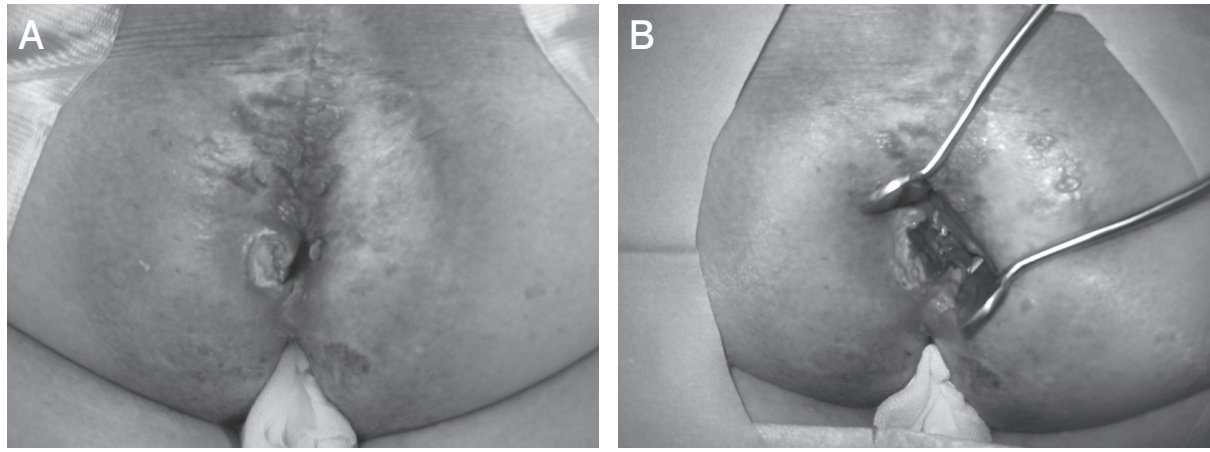

Fig. 4 局所所見

A：肛門縁周辺には尖圭コンジローマの合併を, 肛門管 2 時の方向には潰瘍形成を認めた.

$\mathrm{B}$ ：肛門縁の潰瘍は歯状線口側 $1 \mathrm{~cm}$ まで連続し, 自壊傾向にあり白苔で被覆されていた。 これを頂 点として鶏卵大の腫瘤を形成していた。

T2WI で iso〜low intensity の腫瘤を認めた。

局所所見 (Fig. 4A，B)：肚門管 2 時方向に主座を 置く, 鶏卵大で弾性軟な腫瘤を触知した。肛門管内 は皮膚縁から歯状線口側 $1 \mathrm{~cm}$ まで連続する潰瘍を 形成し，自壊壊死傾向で，皮膚縁部は白苔で被覆さ れていた。
病理組織学的検査所見 (Fig. 5A, B) : 皮膚周辺に は間質のリンパ球や好中球など炎症細胞の浸潤や浮 腫を認めるが, 腫瘍性変化はなかった。潰瘍底を中 心に大型の異形リンパ球の浸潤を認め, これに一致 して免疫染色で $\mathrm{CD} 20(+), \mathrm{CD} 79 \mathrm{a}(-), \mathrm{CD} 3(-)$, CD56(-), と B 細胞性パターンを示し, EBER-ISH 

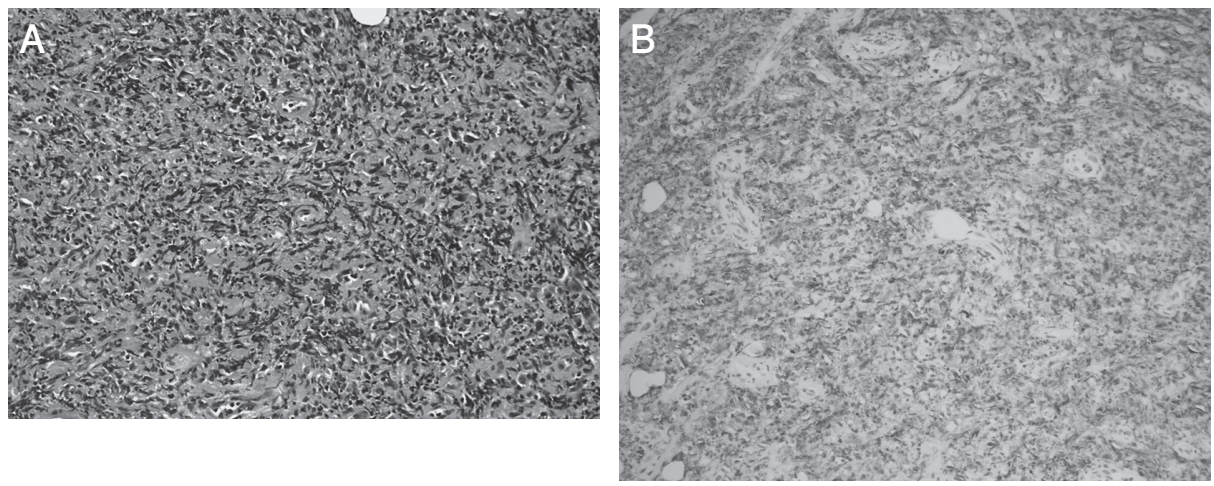

Fig. 5 病理組織学的所見

A：潰瘍底を中心に大型の異形リンパ球のびまん性浸潤を認めた（HE, 200 倍)。

B ：CD20 陽性（200 倍).

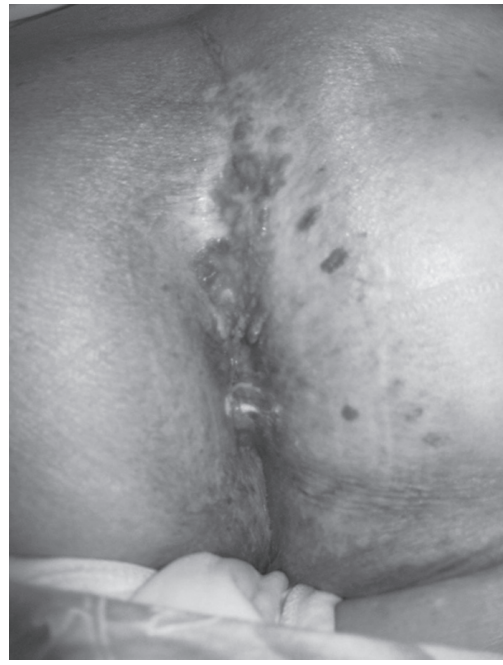

Fig. 6 治療後局所所見 皮膚縁に認めた潰瘍は消失していた。

（+）であった.

治療経過：以上ょり, EBV 陽 性 DLBCL, Ann Arbor IV 期, International Prognostic Index（以下 IPI）high risk，およびATL と診断した，予後不良 な状態と考えたが，ADLやPS が良好でありかつ本 人，家族が積極的な治療を希望されたので，化学療 法の方針とした。高齢のため標準量のおよそ半分の CHOP (CPA500mg/ADM30mg/VCR $1 \mathrm{mg} / \mathrm{PSL}$ $50 \mathrm{mg})$ を導入した。初回投与後特に問題なく退院さ れたが，投与 10 日目から 37 度台の発熱と口内炎症 状の出現を認め, 投与 14 日目に症状悪化のため再入 院となった。肚門部症状は消失しており, 皮膚縁の 潰瘍の消失 (Fig. 6) と腹部 CT 検査でリンパ腫病変 の縮小を認めた. sIL2-R も 7,600U/ml と治療前に比
ベて半減していた。胸部 CT 検査で両側に間質陰影 増強を認め, カリニ肺炎と診断した. ST 合剂投与 を開始したが，急速に深在性真菌血症や口腔食道力 ンジ夕症を発症し, 治療開始 1 力月後に死亡した.

\section{考察}

消化管悪性リンパ腫は全身のリンパ節以外の臓器 に発生する節外性リンパ腫であり，そのほとんどは NHLに属する。鼻腔・Waldeyer 咽頭輪・皮膚など の原発が節外性リンパ腫の $50 \%$ を占め, 胃・小腸・ 大腸などの消化管リンパ腫が $30 \%$ とそれに次ぐ3. 従来腸管原発悪性リンパ腫の定義は病期 I / II 期に 限定したDawsonの基準 ${ }^{4}$ が用いられていたが，近 年はIV 期までを含む Lewin の基準 ${ }^{5}$ が用いられるこ とが多い。すなわち「リンパ腫診断時, 明らかに消 化管に主腫瘍が存在するもの，またはそれによる消 化管症状が存在するもの」とされ, 自験例もこの定 義に該当し肛門管原発と考えられる。

肛門管に発生した悪性リンパ腫は非常に稀で, Bhama らは直腸肛門部の悪性腫瘍の $0.1 \sim 0.3 \%$ と報 告している ${ }^{6)}$. 第 11 回大腸癌研究会の大腸非上皮性 腫瘍の全国集計アンケートによれば, 130 例の大腸 悪性リンパ腫に打ける肚門管病変はわずか 2 例 (1.5\%) であった ${ }^{7)}$. 肛門管リンパ腫は海外では男性 同性愛者がほとんどで Aquied Immune Deficiency Syndrome（以下 AIDS）発症例が多い ${ }^{8)}$. 本来リン パ節組織の存在しない肛門周囲にリンパ腫が発生す る原因として mucosa-associated lymphoid tissue （以下 MALT）が関与しているとされ，同性愛男性 間の肛門性交による様々な肛門感染症と物理学的刺 
激が後天的 MALTを形成し, AIDS などによる細胞 性免疫の低下の影響でリンパ腫へ進展すると考えら れている ${ }^{9}$.

治療では切除可能な病変に対しては積極的に外科 手術が選択されるが，大腸肛門領域の悪性リンパ腫 は根治度 Aの手術であっても高率に再発が認めら れており, 術後の化学療法が勧められている ${ }^{10)}$. ビ ンクリスチン・エンドキサン・アドリアマイシン・ ステロイドの 4 凰併用 CHOP が標準治療とされ, 近 年はそれに抗 CD20 抗体（リッキシマブ）を併用す る R-CHOP が CD20 抗体陽性例に行われている.

自験例の治療に関して主症状の原因である NHL と，合併している ATLのどちらを優先するかが問 題となる.ATL は CD4 陽性 T 細胞に由来した極め て悪性度の高い白血病で, 既存の抗癌剂に対して抵 抗性であり, 発症すると平均 1 年ほどで死亡すると される.一方 Ann Abor IV 期で IPI high risk に相当 する DLBCL の予後は 1 年生存率で $40 \%$ と予想さ れた. ATLの予後が治療にかかわらず非常に悪いこ と, 症状が肛門悪性リンパ腫によるものでかつ積極 的な治療を強く希望したため, いずれの疾患にも適 応となる $\mathrm{CHOP}$ (標準量の半分) を選択した。覀性 リンパ腫への効果は 1 クール終了して RECIST bese line PR (57\%) で非常に良好であったが，早 期に感染性合併症（深在性真菌症, 消化管カンジダ 症）を併発し投与後 1 カ月で死亡した.

これらの経過すなわち (1) ATL の存在, (2) DLBL の発症, (3)肛門尖圭コンジローマの合併, (4)種々の 感染性合併症をふまえると, ATL 発症による強い細 胞性免疫の低下が背景にあったことが推察される。 ATL は高月ら ${ }^{11} に よ り$ 発見されたへルパーT 細胞 の腫瘍で, 「HTLV-1 感染細胞が腫瘍性増殖を示した もの」と定義され，母乳経由の感染のみが臨床上問 題となり, 約 50～70 年の潜伏期を経て発症する. 免 疫担当細胞である $\mathrm{T}$ 細胞の腫瘍化のため, 強い免疫 不全から種々の感染症 (真菌, 原虫, 寄生虫, ウイ ルスなど）による日和見感染を高頻度に合併する。 同じく CD4 陽性 T 細胞に感染するウイルスとして HIV（HTLV- III）があるが，ATL が T 細胞の腫瘍 化であるのに対し，AIDS は T 細胞のアポトーシス である点が異なる. AIDS 指標疾患として Kaposi 肉 腫・NHL・原発性脳リンパ腫・子宮頸癌があげら れるが, 近年の抗 HIV 薬の開発と多剤併用療法によ
り予後が改善され慢性疾患化する一方で, Kaposi 肉 腫の発生が減少し悪性リンパ腫の合併が最も多く なっている. 病態は異なるものの共通するのは $\mathrm{T}$ 細 胞の機能不全であり，自験例での DLBCL 発症や 種々の感染性合併症を生じた原因を ATL 発症によ る細胞性免疫低下と推察した。 2011 年に梅枝ら ${ }^{2}$ が 報告した過去 10 年間における肛門管悪性リンパ腫 13 症例 $6,9,12-16)$ では, 10 例に何らかのウイルス感染 $(\mathrm{HIV}+\mathrm{EBV} 9$ 例・EBV 単独 1 例）を合併していた 点からも, その発症に細胞性免疫の低下が関与する 可能性が示唆されるが, ATL と肛門悪性リンパ腫の 報告は自験例以外になく発症誘因に関しては今後の 症例集積に期待したい.

\section{結語}

肛門原発 DLBCL を経験したが, その発症にATL による細胞性免疫の低下が関与したと考えた。本邦 での報告例は極めて少なく稀な疾患であるが，肚門 診療においては常に念頭に置いておく必要がある.

\section{文献}

1) Stepherd NA, Hall PA, Coates PJ, et al: Primary malignant lymphoma of the colon and rectum. A histopathological and immunohistochemical analysis of 45 cases with clinicopathological correlations. Histopathology $12: 235-252,1998$

2）梅枝 覚, 松本好市, 北川達士ほか：肚門悪性リンパ腫 の 1 例. 日本大腸肛門病会誌 $64: 332-336,2011$

3）松本繁己, 大津 敦, 吉田茂昭ほか：消化管悪性リンパ 腫と全身性悪性リンパ腫とのかかわり一臨床の立場か ら。胃と腸 $33: 314-324,1998$

4) Dawson IMP, Cornes JS, Morson BC, et al: Primary malignant lymphoid tumours of the intestinal tract: Report of 37 cases with a study of factor influencing prognosis. Br J Surg 49 : 80-89, 1961

5) Lewin KL, Ranchod M, Dorfman RF: Lymphomas of the gastrointestinal tract: A study of 117 cases presenting with gastrointestinal disease. Cancer 42 : 693707, 1978

6) Bhama JK, Azad NS, Fisher WE: Primary anorectal lymphoma presecting as a perianal abscess in an HIVpositive male. Eur J Surg Oncol 28 : 195-197, 2002

7）綿貫 喆：第 11 回大腸癌研究会非上皮性腫瘍アンケー 卜調査. 東京, 1980

8) Ioachim H, Antonescu C, Giancotti F, et al: EBV-associated anorectal lymphomas in patients with acquired Immune Deficiency Syndrome. Am J Surg Pathol 21 : 997-1006, 1997

9) Place R, Huber P, Simmang C, et al: Anorectal Lymphoma and AIDS: An Outcome Analysis. J Surg Oncol $73: 1-5,2000$ 
10）堀 智英, 村林紘二, 赤坂義和：大腸原発悪性リンパ腫 の 4 例. 日臨外会誌 $64: 1770-1708,2003$

11) Uchiyama T, Yodoi J, Sagawa K, et al: Adult T-cell leukemia: clinical and hematological features of 16 cases. Blood 50 : 481-491, 1977

12) Lim JH, Lee MH, Lee MJ: Plasmablastic Lymphoma in the Anal Canal. Cancer Res Treat $41: 182-185,2009$

13）山本博通, 森脇秀一, 古谷洋晃ほか：放射線治療を施行 した直腸・肛門 MALT リンパ腫の 5 例—OCRO 参加岡 山大学関連多施設症例の検討一. 日放腫会誌 $20: 163-$ 166, 2008
14) Freudenberg S, Palma P, Grobholz R, et al: HIV-related and Epstein-Barr Virus-associated Aanal Burkitt's Lymphoma: Report of a Case. Dis Colon Rectum 48 : 1656-1659, 2005

15) Siddique K, Bhandari S, Harinath G: Epstein-Barr virus (EBV) positive anal B cell lymphoma: a case report and review of literature. Ann R coll Surg Engl $92: 1-5$, 2010

16) Ganeshan A, Soonawalla ZF, Baxter JN: Perianal Abscess: An Unusual Presentation of Non-Hodgkin's Lymphoma. Eur L Surg 168 : 657-659, 2002

\title{
A Case of Anal Malignant Lymphoma Coexistent with Adult T-cell Leukemia
}

\author{
Katsuhisa Ohashi ${ }^{1}$, Akinori Sasaki ${ }^{1}$, Yoshihiro Matsuo ${ }^{1)}$ and Katsuhide Ohashi ${ }^{2)}$ \\ ${ }^{1}$ Juzen Jeneral Hospital, ${ }^{2}$ Department of Surgery and Gastroenterology and Proctrogy, Ohashi Clinic
}

Anorectal malignant lymphoma is rare, with an incidence reported to be $0.2 \%$ of colorectal malignancy, and anal malignant lymphoma is also quite rare. Anal malignant lymphoma is often associated with homosexual males overseas, related to cellular immunodeficiency, but is rarely seen in Japan. There is no established therapy; although surgery or chemotherapy is effective in some cases, the prognosis is extremely poor. We report a case of anal malignant lymphoma with adult Tcell leukemia, who was found to have HTLV-1 infection. Low-dose CHOP therapy led to early therapy-related death complicated with several infectious diseases. We infer the influence of strong cellular immunodeficiency as a background factor. 